Original Research Paper

\title{
Ethyl Methane Sulfonate (EMS) Effect on Mutagenesis in Balinese Red Rice (Oryza sativa cv. Barak Cenana)
}

\author{
Ida Bagus Made Arta Dana ${ }^{1 *}$, Popy Hartatie Hardjo' ${ }^{1,}$ Maria Goretti Marianti \\ Purwanto $^{1}$, Aloysia Sri Pujiyanti ${ }^{1}$, Indriyani ${ }^{1}$, \\ ${ }^{1}$ Faculty of Biotechnology, University of Surabaya, Surabaya Jalan Raya Kalirungkut, Surabaya 60292, \\ East Java, Indonesia
}

\author{
Article History \\ Received : July $18^{\text {th }}, 2021$ \\ Revised : August $25^{\text {th }}, 2021$ \\ Accepted : September $05^{\text {th }}, 2021$ \\ Published : September $15^{\text {th }}, 2021$ \\ *Corresponding Author: \\ Ida Bagus Made Artadana, \\ Fakultas Teknobiologi, \\ Universitas Surabaya, Indonesia \\ Email: arta@staff.ubaya.ac.id
}

\begin{abstract}
Barak Cenana" is one of the local red rice (Oryza sativa) with high economic value due to its nutrient content. Some of the agronomic characters such as tall shoot, low number of tiller, and late harvesting are drawbacks to improving production. Ethyl Methyl Sulphonate (EMS) is a chemical mutagen widely used to improve rice characters by mutation breeding. The present research aims to investigate the EMS concentration suitable to induce mutation in Barak Cenana and observe the mutagenesis effect of EMS on some agronomic characters of Barak Cenana. For those purposes, mature seeds of Barak Cenana were treated with various concentrations of EMS $(0.25,0.5,0.75,1.0$, and $1.1 \%)$ for 24 hours. Seed germination, plant growth, some agronomic character related to productivity were compared to untreated rice. EMS reduced and delayed seed germination and inhibit shoot and root growth in early vegetative stage. The ability of EMS to reduce and delay seed germination and inhibit shoot and root growth were doses dependent. EMS concentration of more than $1.0 \%$ was lethal for Barak cenana and EMS concentration at $0.75 \%$ was able to reduce rice productivity by increasing seed sterility. EMS concentrations between 0.25 and $0.5 \%$ with $24 \mathrm{~h}$ of soaking are suitable for inducing mutagenesis in Barak Cenana. Additionally, some mutants with distinct morphology such as sterile plant, semi-dwarf, high tillering capacity, and high chlorophyll contents were produced in this research.
\end{abstract}

Keywords: EMS; Mutagenesis; Agronomic; Germination;

Productivity

\section{Pendahuluan}

Barak cenana adalah salah satu jenis padi lokal dari Kabupaten Tabanan-Bali (Widarta et al., 2013). Sampai saat ini, petani masih tetap menanam Barak Cenana secara turun-temurun karena memiliki harga yang tinggi yang disebabkan oleh tingginya kandungan nutrisi pada beras yang dihasilkan (Darmiati et al., 2019). Indrasari (2011) melaporkan bahwa Barak Cenana kaya vitamin $\mathrm{B}$ dan antioksidan dalam bentuk antosianin. Namun demikian, jenis padi Barak Cenana memiliki usia yang panjang (180-190 hari) dan batang yang tinggi $(>170 \mathrm{~cm})$ sehingga berdapak pada produktivitasnya (Wiryatama, 2007). Padi dengan batang tinggi rentan rebah ketika memasuki fase reproduksi dan berakibat pada hilangnya gabah yang dapat di panen (Mackill et al., 1996). Sementara itu, usia tanaman yang panjang mengakibatkan padi jenis Barak Cenana hanya mampu di tanam sekali dalam setahun (Subagyo, 2012).

Mutasi telah lama di manfaatkan untuk pemuliaan tanaman pangan (Oladosu et al., 2016; Chaudhary et al., 2019). Mutagen kimia atau fisika dapat mengubah susunan genom organisme sehingga dapat merubahan sifat-sifat organisme tersebut (FAO, 2011: Viana et al., 2019).. Pada tanaman padi, mutasi telah berhasil 
dimanfaatkan untuk mengurangi tinggi tanaman (Phanchaisri et al., 2017; Boonrueng et al., 2013) dan usia tanam (Singh et al., 2000), dan meningkatkan ketahananya terhadap cekaman garam (Artadana et al., 2014; Theerawitaya et al., 2012).

Etil metil sulfonate (EMS) adalah salah satu mutagen kimia yang banyak dipergunakan untuk pemuliaan tanaman padi. EMS memicu terjadinya mutasi berupa perubahan pasangan basa DNA dari C/G menjadi A/T (Ramchader et al., 2014; Viana et al., 2019). Mutasi missense atau nonsense yang dipicu oleh EMS dapat mengubah struktur dan fungsi protein sehingga mengakibatkan perubahan pada satu atau beberapa sifat tanaman. Secara umum, konsentrasi EMS yang dipergunakan untuk memutasi tanaman padi berkisar antara $0.1 \%$ to 2 (Veni and Niveditha, 2014; Mohapatra et al., 2014; Wattoo et al., 2013). Penelitian ini bertujuan untuk mengetahui konsentrasi EMS yang tepat untuk menginduksi mutasi dan pengaruhnya terhadap perubahan fenotip dari padi Barak Cenana.

\section{Bahan dan Metode}

\section{EMS mutagenesis}

Biji Barak Cenana diperoleh dari petani

di desa Jatiluwih, Kecamatan Penebel, Kabupaten Tabanan-Bali. Mutasi dilakukan berdasarkan metode yang dijelaskan pada Ramchander et al. (2014) dengan sedikit modifikasi. Gabah dikupas dengan tangan dan kemudian beras direndam pada larutan EMS dengan kadar $0 \%, 0,25 \%, 0,50 \%, 0,75 \%, 1,0 \%$, atau $1,1 \%(\mathrm{w} / \mathrm{v})$ selama $24 \mathrm{jam}$. Biji kemudian dicuci sebanyak tiga kali dengan air destilasi masing-masing selama 3 menit dan dilanjutkan dengan pencucian menggunakan air destilasi sebanyak 4 kali masing-masing selama 15 menit. Biji-biji tersebut dikecambahkan di dalam petri yang mengandung kertas saring basah. Tujuh hari setelah perkecambahan, semua bibit dipindahkan ke dalam pot berisi tanah dengan campuran tanah dan kompos dengan perbandingan 1:1 sampai masa panen.

\section{Karakterisasi pasi hasil mutasi}

Pengamatan dilakukan pada fase perkembangan dan beberapa karakter morfologi selama masa vegetatif dan reproduktif.
Pengukuran tinggi tanaman dilakukan pada fase vegetatif dan reproduktif. Pada fase vegetatif, tinggi diukur dari pangkal batang sampai daun tertinggi sedangkan pada fase generatif tinggi diukur dari pangkat batang sampai ujung malai tangkai utama. Beberapa karakter agronomik diukur pada usia panen antara lain jumlah dan karakteristik malai, jumlah gabah per tanaman, persentase gabah isi dan berat 100 biji.

Uji viabilitas polen dilakukan pada malai steril (malai tanpa biji) berdasarkan metode yang dipaparkan oleh Waheed et al. (2013). Polen di ambil pada saat antesis dan diwarnai menggunakan larutan $\mathrm{I}_{2} \mathrm{KI} 1 \%$.

\section{Uji statistik}

Semua data dianalisis menggunakan uji one-way analysis of variance (ANOVA) at $\alpha=$ $5 \%$ mengunakan program SPSS. Adanya perbedaan antar perlakuan dianalisa menggunakan metoda Duncan Multiply Range Test (DMRT) pada tingkat kepercayaan 5\%.

\section{Hasil dan Pembahasan}

\section{Pengaruh konsentrasi EMS terhadap perkecambahan}

Perendaman dengan EMS mengakibatkan terhambatnya perkecambahan pada biji padi Barak Cenana. Persentase biji yang berkecambah menurun seiring dengan meningkatnya konsentrasi EMS (Tabel 1 and Gambar 1A). Perkecambahan mengalami penurunan signifikan ketika diberi perlakuan EMS dengan konsentrasi $\geq 0.75 \%$ dan mencapai LD 50 pada konsentrasi EMS 1, 10\%.

Biji yang direndam dengan EMS menunjukkan adanya penundaan perkecambahan. Perendaman biji pada larutan EMS dengan konsentrasi 0,25, 0,50, 0,75, 1,00 dan $1,10 \%$ secara berturut-turut mengakibatkan biji berkecambah 1, 2, 3, 4 dan 5 hari lebih lama dibandingkan kontrol (Tabel 1). 
Table 1 Persentase dan waktu perkecambahan dari padi Barak cenana yang diberi perlakukan EMS dengan berbagai konsentrasi

\begin{tabular}{|c|l|c|}
\hline $\begin{array}{l}\text { Konsentr } \\
\text { asi EMS } \\
(\%)\end{array}$ & $\begin{array}{l}\text { Perkecambahan } \\
(\%)\end{array}$ & $\begin{array}{l}\text { Waktu } \\
\text { perkecabahan } \\
\text { (hari setelah } \\
\text { perlakuan) }\end{array}$ \\
\hline 0,00 & $\begin{array}{l}100,00 \pm 0,00^{\text {a }} \\
(40 / 40)\end{array}$ & $1,50 \pm 0,57^{\mathrm{a}}$ \\
\hline 0,25 & $\begin{array}{l}97,50 \pm 0,050^{\mathrm{a}} \\
(39 / 40)\end{array}$ & $2,50 \pm 0,57^{\mathrm{b}}$ \\
\hline 0,50 & $\begin{array}{l}87,50 \pm 0,05^{\text {ab }} \\
(35 / 40)\end{array}$ & $4,00 \pm 0,00^{\mathrm{c}}$ \\
\hline 0,75 & $\begin{array}{l}72,50 \pm 0,05^{\mathrm{b}} \\
(29 / 40)\end{array}$ & $5,00 \pm 0,00^{\mathrm{d}}$ \\
\hline 1,00 & $\begin{array}{l}67,50 \pm 0,95^{\mathrm{bc}} \\
(27 / 40)\end{array}$ & $6,00 \pm 0,00^{\mathrm{e}}$ \\
\hline 1,10 & $\begin{array}{l}50,0 \pm 0,18^{\mathrm{c}} \\
(20 / 40)\end{array}$ & $7,00 \pm 0.00^{\mathrm{f}}$ \\
\hline
\end{tabular}

Keterangan: Huruf berbeda menunjukan adanya perbedaan nyata $(\mathrm{p}<0,05)$ setelah dianalisa dengan Duncan Multiple Range Test pada $\alpha=5 \%$.

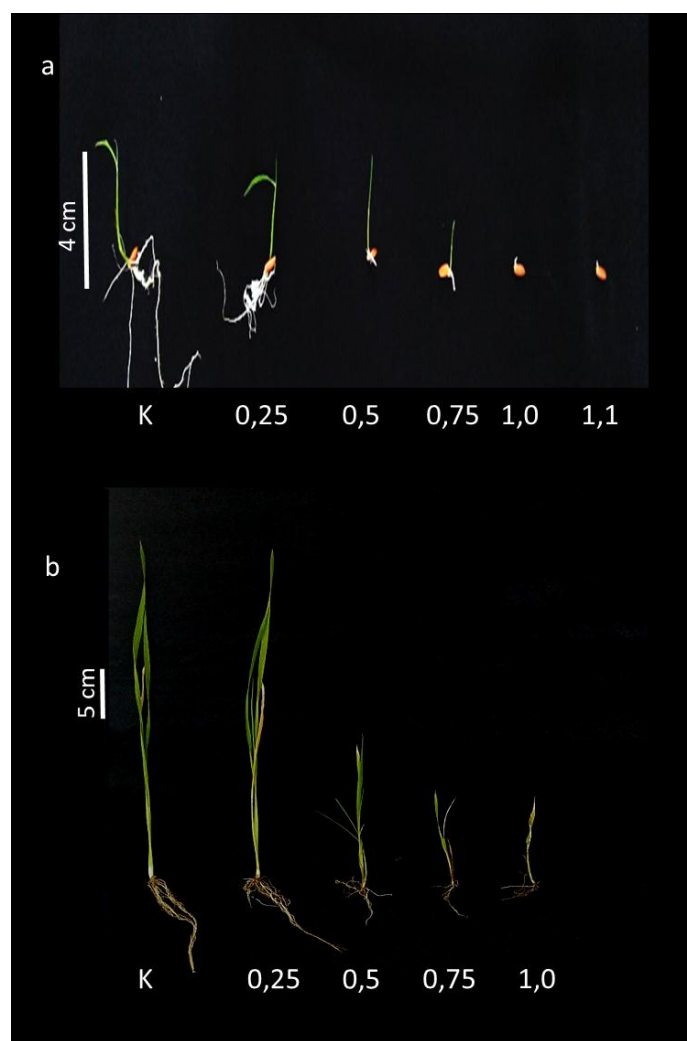

Gambar 1. Pengaruh EMS terhadap pertumbuhan akar dan tinggi padi Barak cenana. A. awal fase vegetatif; B. 30 hari setelah perkecambahan.

\section{Pengaruh EMS pada fase vegetatif}

EMS menurunkan tinggi dan panjang akar pada fase vegetatif awal. Tujuh hari setelah perendaman dengan EMS, akar menunjukkan pertumbuhan yang lambat terutama pada padi yang mendapat perlakukan EMS dengan konsentrasi di atas $0,25 \%$. Bahkan pertumbuhan akar tidak teramati pada tanaman yang mendapat perlakukan 1\% dan 1,1\% EMS (Gambar 2a). Sama seperti pertumbuhan akar, EMS dengan kadar diatas $0,25 \%$ juga terlihat menurunkan tinggi tanaman. Pengaruh EMS terhadap pertumbuhan akar dan tinggi tanaman masih teramati sampai padi berusia 30 hari setelah perkecambahan. Padi yang mendapat perlakuan $0,25,0,5,0,75$ dan $1 \%$ EMS memiliki panjang akar 35,5\%,67,6\%, 52,8\%, and 78,5\%, lebih pendek dari kontrol (Gambar 2). EMS dengan konsentrasi $0,25 \%$ tidak mengakibatkan penurunan tinggi tanaman, namun konsentrasi di atas itu mengakibatkan penurunan signifikan pada pertumbuhan pucuk. Padi yang mendapat perlakuan EMS dengan konsentrasi 0,50, 0,75 dan $1,00 \%$ memiliki tinggi $16,83,64,6$, dan $74,2 \%$ lebih rendah dari kontrol. Selain itu, EMS juga menyebabkan penurunan persentase kesintasan tanaman padi pada usia 30 hari setelah perkecambahan.

Variasi fenotip teramati pada padi yang tumbuh dari biji yang mendapat perlakuan EMS. Berdasarkan tinggi tanaman terdapat dua kelompok tanaman yaitu tanaman dengan batang tinggi dan tanaman dengan batang sedang, berdasarkan diameter batang terdapat padi dengan batang lebar dan ramping, berdasarkan watu munculnya anakan terdapat padi dengan waktu muncul anakan cepat dan lambat, dan berdasarkan muculnya daun bendera juga terdapat tanaman dengan waktu muculnya daun bendera yang cepat dan lambat (Tabel 2). 


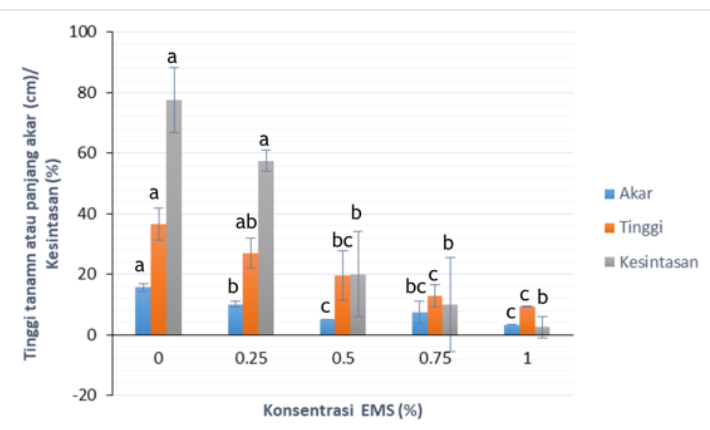

Gambar 2. Pengaruh EMS terhadap tinggi tanaman, panjang akar dan kesintasan tanaman pada usia 30 hari setelah perkecambahan. Huruf yang berbeda menunjukkan nilai yang berbeda secara signifikan pada $\mathrm{p}<$ 0,05 setelah dianalisa menggunakan Duncan Multiple Range Test pada $\alpha=$ $5 \%$.

Tabel 2. Variasi fenotip yang teramati pada padi yang tumbuh dari biji yang mendapat perlakukan EMS.

\begin{tabular}{|c|c|c|c|}
\hline Fenotip & Klasifikasi & Rentang & $\begin{array}{c}\text { Persentase } \\
\text { mutan } \\
\text { putatif }\end{array}$ \\
\hline \multirow{3}{*}{ Tinggi } & Tinggi & $>140$ & 94 \\
\hline & Sedang & $120-140$ & 6 \\
\hline & Pendek & $<120$ & - \\
\hline \multirow{2}{*}{$\begin{array}{l}\text { Jumlah } \\
\text { Anakan }\end{array}$} & Banyak & $>6$ & 3 \\
\hline & Sedikit & $<5$ & 97 \\
\hline \multirow{2}{*}{$\begin{array}{l}\text { Diameter } \\
\text { batang }\end{array}$} & Lebar & $\geq 1,0$ & 25 \\
\hline & Ramping & $\leq 0,9$ & 75 \\
\hline \multirow{2}{*}{$\begin{array}{l}\text { Waktu } \\
\text { munculnya } \\
\text { anakan }\end{array}$} & Cepat & $<60$ & 6 \\
\hline & Lambat & $>61$ & 94 \\
\hline \multirow{2}{*}{$\begin{array}{l}\text { Munculnya } \\
\text { daun bendera }\end{array}$} & Cepat & $\leq 110$ & 25 \\
\hline & Lambat & $>111$ & 75 \\
\hline
\end{tabular}

\section{Produktivitas padi yang diberi perlakuan EMS}

Dari tiga parameter produktivitas yang diukur, hanya persentase gabah isi yang menunjukkan perbedaan signifikan (Tabel 3). Padi dengan perlakukan $0,75 \%$ EMS memiliki persentase gabah isi 55\% lebih rendah dari kontrol.
Tabel 3. Pengaruh EMS terhadap produktivitas tanaman Padi

\begin{tabular}{|c|c|c|c|}
\hline $\begin{array}{l}\text { Konsentr } \\
\text { asi EMS } \\
(\%)\end{array}$ & $\begin{array}{c}\text { Jumlah } \\
\text { gabah isi }\end{array}$ & $\begin{array}{c}\text { Persentase } \\
\text { gabah isi }\end{array}$ & $\begin{array}{c}\text { Berat 1000 } \\
\text { biji }(\mathrm{g})\end{array}$ \\
\hline 0,00 & 230,638 & $60 \pm 0,164^{\mathrm{a}}$ & $\begin{array}{c}28,71 \pm \\
1,399\end{array}$ \\
\hline & $463 \pm$ & & $28,83 \pm$ \\
0,25 & 158,314 & $54 \pm 0,295^{\text {ab }}$ & 1,406 \\
\hline & $555 \pm$ & & $28,73 \pm$ \\
0,50 & 183,875 & $38 \pm 0,448^{\text {ab }}$ & 1,685 \\
\hline & $414 \pm$ & & $27.89 \pm$ \\
0,75 & 110,211 & $27 \pm 0,255^{\text {b }}$ & 1,833 \\
\hline
\end{tabular}

Keterangan: huruf yang sama pada table menunjukkan perbedaan signifikan pada $\mathrm{p}<0,005$ setelah dianalisis dengan Duncan Multiple Range Test pada $\alpha=5 \%$.

\section{Mutan putatif dengan karakter unik}

Lima muntan putatif dengan karakter unik teramati pada penelitian ini (Table 4). Tiga mutan putatif memiliki malai steril yang salah satunya disebabkan oleh gagalnya polen mengalami pematangan (Gambar 3). Salah satu dari ketiga mutan putatif steril memiliki tinggi kurang dari $140 \mathrm{~cm}$. Mutan putatif 5A1.0 memiliki banyak anakan dan mutan putatif $3 \mathrm{C} 0.5$ memiliki kandungan klorofil yang tinggi di daunnya meski mengalami pertumbuhan yang lambat.

Tabel 4. Mutan putatif dengan karakter unik

\begin{tabular}{|l|l|}
\hline Putatif mutan & Karakter unik \\
\hline $3 \mathrm{~A} 0.5$ & $\begin{array}{l}\text { Malai steril, tinggi sedang (136 } \\
\mathrm{cm})\end{array}$ \\
\hline $3 \mathrm{D} 0.5$ & Malai steril \\
\hline $4 \mathrm{~A} 0.75$ & Mala steril \\
\hline $3 \mathrm{C} 0.5$ & $\begin{array}{l}\text { Pertumbuhan lambat dan kadar } \\
\text { klorofil yang tinggi di daun. }\end{array}$ \\
\hline 5A 1.0 & Memproduksi banyak anakan \\
\hline
\end{tabular}

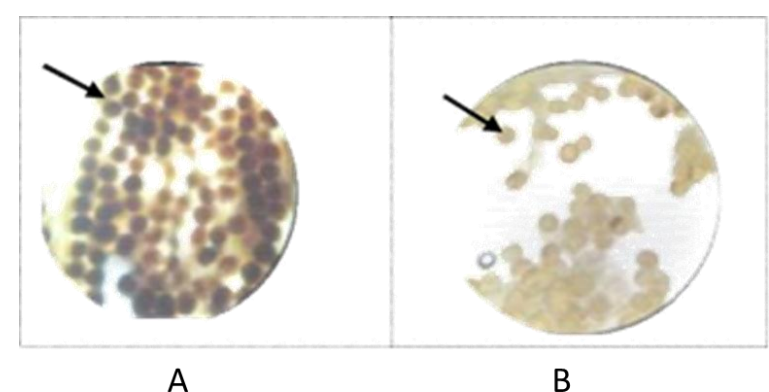

Gambar 3. Hasil uji viabilitas polen dari padi kontrol (A) dan mutan putative (B) dengan malai steril. Tanda panah menunjukkan polen. 


\section{Pengaruh EMS terhadap perkecambahan}

Hasil penelitian ini menunjukkan bahwa kemampuan dari EMS dalam menghambat perkecambhaan tegantung pada dosis yang diberikan. Persentase biji yang berkecambah menurun seiring dengan meningkatnya konsentrasi EMS. Hasil ini sejalan dengan yang dilaporkan oleh Ramchander et al. (2014) pada padi var White ponni and BPT 5204, Mohapatra et al. (2015) pada padi var. Nagina 22, Talebi et al. (2012) pada padi cv. MR219, Wattoo et al. (2013) pada padi Basmati, dan Ali et al. (2019) Dawk-Payawm dan Dawk Kha 50. Menurut Xuebao (1991), EMS menghambat respirasi pada biji, aktivitas sitokrom oksidase dan enzim amilase sehingga menyebabkan terhambatnya perkecambahan biji. Kondisi serupa diduga menjadi penyebab terhambatnya perkecambahan pada padi Barak cenana yang mendapat perlakukan EMS.

LD50 merupakan parameter yang penting dalam melakukan pemuliaan pada tanaman secara mutagenesis. Umumnya dosis yang dipakai untuk mutagenesis lebih rendah dari LD50. LD 50 dari padi barak cenana berada pada dosis EMS 1,1\% dengan perendaman selama 24 jam. Nilai ini sama dengan LD 50 dari padi Basmati (Wattoo et al., 2013) dan lebih tinggi dari padi and e cv MR219 (Talebi, 2012). Dengan mempertimbangkan persentase perkecambahan dan kesintasan, konsentrasi EMS yang dipergunakan pada mutagenesis padi barak cenana di masa depan ada dikisaran 0,25-0,5\%.

\section{Pengaruh EMS terhadap pertumbuhan}

Penelitian terdahulu menunjukkan bahwa pemberian EMS tidak hanya menghambat perkecambahan, melainkan juga pertumbuhan akar dan tinggi tanaman padi (Talebi et al., 2012; Ramchander et al., 2014; Ali et al., 2019). Peristiwa yang sama juga teramati pada penelitian ini. Pertumbuhan tinggi dan akar menurun seiring dengan meningkatnya konsentrasi EMS yang diberikan. Fenomena ini diduga muncul akibat adanya ganguan fisiologi dan pembelahan sel yang timbul akibat pemberian EMS pada biji. Seperti telah dikemukakan sebelumnya, Xuebao (1991) menemukan bahwa EMS menyebabkan penurunan laju respirasi, aktivitas sitokrom oksidase, dan amilase pada bibit padi sehingga berdampak pada pertumbuhan tanaman padi.
Beberapa penelitan menunjukkan bahwa konsentrasi EMS yang tinggi dapat menyebabkan kerusakan kromosom pada jaringan meristematik akar (Rani and Kumar, 2015; Verma et al., 2012; Patil and Bhat, 1992). Pada cabai (Capsicum annum L.). Kerusakan kromosom yang diinduksi oleh EMS berkaitan erat dengan menurunnya laju pertumbuhan dan pembelahan mitosis pada akar (Devi and Mullainathan, 2011).

EMS merupakan mutagen kimia yang menyebabkan terjadinya mutasi berupa perubahan basa dari $\mathrm{A} / \mathrm{G}$ menjadi $\mathrm{C} / \mathrm{T}$. Mutasi yang terjadi bersifat acak sehingga memicu terjadinya varisi genetik. Variasi gentik dapat terekspresi dalam bentuk variasi fisiologi, perkembangan ataupun morfologi (Viana et al., 2019). Variasi morfologi pada tanaman padi yang mendapat perlakukan EMS juga ditemukan pada penelitian ini dalam bentuk variasi tinggi, waktu munculnya anakan dana daun bendera, diameter batang dan jumlah anakan. Adanya variasi tersebut mengindikan EMS yang diberikan kemungkinan menyebabkan mutasi pada padi Barak cenana. Untuk membuktikan hal tersebut, kedapan dapat dilakukan analisis secara molekuler menggunakan DNA fingerprinting.

\section{Produktivitas padi}

Produktivitas padi ditentukan oleh berat beras yang dihasilkan. Berat beras yang dihasilkan pertanaman sangat tergantung pada beberapa sifat agronomik seperti jumlah malai, jumlah gabah per malai, persentase gabah isi dan berat 1000 biji (Pandey and Anurag, 2010; Hairmansis et al., 2010). Barak cenana yang dimutasi menggunakan $0,75 \%$ EMS menunjukkan adanya penurunan produktivitas yang disebabkan oleh penurunan persentase gabah isi. Salah satu penyebab rendahnya gabah isi adalah rendahnya viabilitas polen. Singh and Singh (2003) melaporkan bahwa pasi Basmati yang ditreatmen dengan EMS kadar tinggi mengalami penurunan gabah isis yang disebabkan oleh rendahnya viabilitas polen.

\section{Mutan putatif dengan karakter unik}

Pada penelitian saat ini, lima putatif mutan dengan karakter yang berbeda dari WT berhasil diperoleh, namun tidak satupun dari mutan tersebut memiliki produktivitas yang lebih tinggi dari WT. Meski demikian, semua putatif 
mutan memiliki potensi untuk dipergunakan dalam meningkatkan produktivitas padi Barak Cenana dengan persilanan konvensional. Tiga putatif mutan memiliki malai steril yang disebabkan oleh hilangnya viabilitas polen. Jantan steril sangat penting dalam persilangan tanaman yang melakukan penyerbukan sendiri seperti padi (Virmani, 1994). Selain itu, mutan putatif 3A0.5 memiliki potensi untuk dimanfaatkan dalam menghasilkan padi Barak cenana dengan dengan pucuk yang lebih pendek. Padi dengan batang pendek tidak mudah patah sehingga dapat mencegah hilangnya gabah pada fase reproduksi (Yan et al., 2012). Mutan putatif 5A1.0 berpotensi dipergunakan untuk meningkatkan produktivitas padi karena memiliki anakan dalam jumlah banyak. Jumlah anakan padi berkolerasi positif dengan jumlah malai dan gabah yang dihasilkan per tanaman (Khush, 2001; Xing and Zhang, 2010). Salah satu pendekatan fisiologis untuk meningkatkan produktivitas tumbuhan adlaah dengan meningkatkan kemampuan menyerap cahaya untuk fotosintesis. Klorofil merupakan molekul yang bertanggung jawab dalam penyerapan energi cahaya dalam fotosintesis. Zang et al. (2012) melaporkan mutan dari padi Gc yang memiliki kandungan klorofil lebih tinggi dari WT juga memiliki laju fotosintesis yang lebih tinggi dari WT. Mutan putatif 3C0.5 memiliki kandungan klorofil yang lebih tinggi dari WT sehingga berpotensi dimanfaatkan untuk meningkatkan kapasitas fotosintesis dari Barak Cenana sehingga produktivitas dari padi ini meningkat. .

\section{Kesimpulan}

Perendaman biji padi Barak cenana dengan konsentrasi $0,5 \%$ atau lebih selama 24 jam meurunkan persentase perkecambahan dan pertumbuhan pada awal fase vegetatif. Sedangkan konsentrasi $0,75 \%$ dapat menurunkan produktivitas padi. Untuk melakukan mutagenesis direkomendasika pada padi barak cenana sebaiknya menggunakan dosis EMS 0,25-0,5\% dengan perendaman selama 24 Jam.

\section{Ucapan terima kasih}

Kami mengucaptak terimakasi atas Pendanaan yang diberikan oleh DIKTI dan
Fasilitas penelitian yang disediakan oleh Fakultas Teknobiologi Uiversitas Surabaya.

\section{Referensi}

Ali, A., C. Nualsri and W. Soonsuwon (2019). Induced mutagenesis for creating variability in Thailand's upland rice (cv. Dawk Pa-yawm and Dawk Kha 50) using ethyl methane sulphonate (EMS). Sarhad Journal of Agriculture, 35(1): 293-301. DOI:

http://dx.doi.org/10.17582/journal.sja/201 9/35.1.293.301

Artadana, I.B.M., Cha-um, S., \& Supaibulwatana, K. (2014). Phenotypic responses of Thai Jasmine rice (Oryza sativa $\mathrm{L}$. KDML 105) and its mutants to sodium chloride stress. Proceeding of 2ndAGRC:66-71.

Boonrueng, N., Anuntalabhochai, S., \& Jampeetong, A. (2013). Morphological and Anatomical Assessment of KDML 105 (Oryza sativa L. spp. Indica) Rice and Its mutants Induced by Low-Energy Ion Beam. Rice Sciece 20(3):-. DOI: https://doi.org/10.1016/S1672-6308

Chaudhary, J., Deshmukh, R., and Sonah, H. (2019). Mutagenesis Approaches and Their Role in Crop Improvement. Plants 8 (467): 1-4. DOI: 10.3390/plants8110467

Darmiati, N. N., Sukmawati, N. M. S., \& Siti, N. W. (2019). Pengolahan beras merah lokal penebel (oryza sativa var. barak cendana) menjadi produk teh beras merah untuk meningkatkan pendapatan masyarakat desa Babahan. Buletin Udayana Mengabdi $18 \quad$ (1): 22-27. https://ojs.unud.ac.id/index.php/jum/articl e/view/46299

Devi A.S., \& Mullainathan (2011). Genotoxicity of Ethyl Methane sulfonate on Root Tip of Chilli (Capsicum annuum L.). World Journal of Agricultural Science 7 (4): 368374 http://www.idosi.org/wjas/wjas7 (4)/1.pdf 
FAO (2011). Plant Mutation Breeding and Biotechnology. FAO, Rome. ISBN 9789251050000 .

Hairmansis A., Kustianto B., Supartopo \& Suwarno (2010). Correlation of Agronomic Characters and Grain Yield of Rice for Tidal Swamp Areas. Indonesia Journal of Agricultural Science 11 (1): 1115.

http://ejurnal.litbang.pertanian.go.id/inde x.php/ijas/article/view/592/373

Indrasari S. D. (2011). Peneliti Gizi dan Makanan 30:182-188. http://ejurnal.litbang.pertanian.go.id/inde x.php/jpptp/article/view/3024

Khush, G. S. (2001). Green revolution: the way forward. Nature review genetic 2: 815-822

Mackill, D. J., Coffman, W. R., and Garrity, D. P. (1996). Rainfeed lowland rice improvement. IRRI, Manila. ISBN 97122-0071-X. p53.

Mohapatra, T., Robin, S., Sarla, N., Sheshashayee. M., Singh, A. K., Singh, K., Singh, N. K., Mithra, S. V. A., ... \& Sharma, R. P. (2014). EMS Induced Mutants of Upland Rice Variety Nagina22: Generation and Characterization. Proc Indian Natn Sci Acad, $\quad 80 \quad$ (1); $\quad$ 163-172. DOI:10.16943/ptinsa/2014/v80i1/55094

Oladosu, Y., Rafi, M. Y., Abdullah, N., Hussin, G., Ramli, A, Rahim, H. A., Miah, G., ... \& Usman, M. (2016). Principle and application of plant mutagenesis in crop improvement: a review. Biotechnology and biotechnological equipment, 30 (1): 116. DOI: https://doi.org/10.1080/13102818.2015.1 $\underline{087333}$

Patil, B.C. and Bhat, G. I. (1992). A comparative Study of MH and EMS in the Induction of Chromosomal Aberrations on Lateral oot Meristem in Clitoria ternatea L. Cytologia, 57: 259-264 https://www.jstage.jst.go.jp/article/cytolo gia1929/57/2/57_2_259/_pdf

Pandey, P. and Anurag, P. J. (2010). Estimation of genetic parameters in indigenous rice. $A A B$ Bioflux, 2 (1): 79-84 http://www.aab.bioflux.com.ro/docs/2010 .2.79-84.pdf

Phanchaisri, B., Chandet, Yu, L. D., Jamjod, S., \& Anuntalabhochai, S. (2007). Lowenergy ion beam-induced mutation in Thai jasmin rice (Oryza sativa L. cv. KDML 105). Surface \& Coating technology, 201: 8024-8028.

DOI: https://doi.org/10.1016/j.surfcoat.2006.02 .057

Ramchander, S., Pillai, M. A., \& Ushakumari, R. (2014). Determine of Lethal Dose and Effect of Ethyl Methane Sulphonate in Rice Varieties. Trend in Bioscience, 7(11): 1151-1156

Rani, N. and Kumar, K. (2015). EMS induced mitotic abnormality in Chatharantus roseous (L.) G. Don. Journal of Global Bioscience. $\quad 4$ : 1816-1823. https://www.mutagens.co.in/jgb/vol.04/1 S/03.pdf

Singh, R. K., Singh, U. S., \& Khush, G. S. (2000). Aromatic rice. New Delhi, Oxford \& IBH Publishing. ISBN: 81-204-1420-9

Singh, S. and Singh, J. (2003) Mutation in basmati rice induced by gamma rays, ethyl methane sulphonate and sodium azide. Oryza, 40 (1-2):5-10

Subagyo, R. (2012). Jatiluwih, Menjaga Warisan Beras Merah. https://bali.antaranews.com/berita/32328/j atiluwih-menjaga-warisan-beras-merah (Accessed on February 4, 2015)

Talebi, A. B., Talebi, A. B., \& Shahrokhifar, B. (2012). Ethyl Methane Sulphonate (EMS) induced mutagenesis in Malaysian rice (cv. MR219) for lethal dose determination. American Journal of Plant Sciences 3:1661-1665. DOI: 
http://dx.doi.org/10.4236/ajps.2012.3122 $\underline{02}$

Theerawitaya, C., Triwitayakorn, K., Kirdmanee, C., Smith, D. R., \& Supaibulwatana, K. (2011). Genetic variation associated with salt tolerance detected in mutants of KDML 105 (Oryza sativa L. spp. Indica) rice. Australian Journal of Crop Science, 5(11): 1475-1480

Veni, B. K. and Niveditha, M. S. (2014). Effect of Mutagens on Quantitative and Qualitative Characters in M3 Generation of Rice Variety 'Akshaya' (BPT 2231). Jounal of Rice Research, 7(1): 16-24. DOI: http://sarr.co.in/Journals/2014/jrrvolume-7-3.pdf

Verma, A. K., Singh, R. R., \& Singh, S. (2012). Cytogenetic effect of EMS on root meristem cell of Chataranthus roseus (L.) G. Don var. Nirmal. International Journal of Pharmacy and Biological Science, 2 (1): 20-24.

https://citeseerx.ist.psu.edu/viewdoc/dow nload?doi=10.1.1.420.7913\&rep=rep1\&t ype $=$ pdf

Viana, V. E., Pegoraro, C., Busanello, C., and de Oliveira, A. C. (2019). Mutagenesis in rice: The basis for breeding a new super rice. Frontier in Plant Science, 10: 1-28. DOI: $10.3389 /$ fpls.2019.01326

Virmani, S.S. (1994). Heterosis and Hybrid Rice Breeding. Springer Berlin Heidelberg

Waheed, A., Ahmad, H., Abbasi, F., Hamid, F. S., Shah, A. H., Safi, F. A., \& Ali, H. (2013). Pollen Sterility in wide crosses derivatives of rice (Oryza sativa L.). J. Mater. Environ. Sci. 4 (3): 404-409. https://www.researchgate.net/publication/ 273766424_Pollen_Sterility_in_wide_cro sses derivatives of rice Oryza sativa L

Widarta, I. W. R., Novianitri, K. A., \& Sari, L. P. I. P. (2013). Ekstraksi komponen bioaktif bekatul beras local dengan beberapa jenis pelarut. Jurnal Aplikasi Teknologi Pangan, 2(2): 75-79. http://www.jatp.ift.or.id/index.php/jatp/ar ticle/view/116

Wiryatama, N.A., (2007). Barak Cenana. Date of registration 83/PVL/2007

Wattoo, J. I. K. A, Shah, S. M., Shabir, G., Sabar, M., Naveed, S. A., Waheed, R., Samiullah, Muqaddasi, Q. H., ... \& Arif, M. (2013). Ethyl methane sulphonate (EMS) induced mutagenic attempts to create genetic variability in Basmatirice. African Journal of Water Conservation and Sustainability, 1(3):45-48. https://citeseerx.ist.psu.edu/viewdoc/dow nload?doi=10.1.1.685.2086\&rep=rep1\&t ype $=$ pdf

Xing, Y. and Zhang, Q. (2010) Genetic and Molecular bases of Rice Yield. The Annual Review of Plant Biology, 61: 11.111.22

DOI: $\quad 10.1146 /$ annurev-arplant-042809112209

Xuebao, L. (1991). Effect of EMS on the germinating seed of rice. Journal of Wuhan Botanical Research, 9(3): 263-267 http://www.whzwxyj.cn/EN/abstract/abst ract474.shtml\#

Yan, W., Hu, B., Zhang, Q., Jia, L., Jackson, A., Pan, X., Huang, B., Yan, Z., ... \& Deren, C. (2012). Short and erect rice (ser) mutant from 'Khao Dawk Mali 105' improve plant architecture. Plant Breeding, 131: 282-285. https://doi.org/10.1111/j.1439$\underline{0523.2011 .01943 . \mathrm{x}}$

Zang, G., Zou, H., \& Wenwen, Y. (2012). Photosyntetic and physilogical analysis of the rice high-chlorophyll mutant $(\mathrm{Gc})$. Plant Physiology and Biochemistry, 60: 81-87. DOI: 10.1016/j.plaphy.2012.07.019 